Volume 9, Issue 1 (Winter 2017)

\title{
Rembrandt's Philosopher: Aristotle in the Eye of the Beholder
}

Menno Jonker

info@mennojonker.nl

Recommended Citation:

Menno Jonker, "Rembrandt's Philosopher: Aristotle in the Eye of the Beholder," JHNA 9:1 (Winter 2017) DOI: 10.5092/jhna.2017.9.1.12

Available at https://jhna.org/articles/rembrandt-philosopher-aristotle-eye-beholder/

Published by Historians of Netherlandish Art: https://hnanews.org/

Republication Guidelines: https://jhna.org/republication-guidelines/

Notes: This PDF is provided for reference purposes only and may not contain all the functionality or features of the original, online publication. This PDF provides paragraph numbers as well as page numbers for citation purposes.

ISSN: 1949-9833 


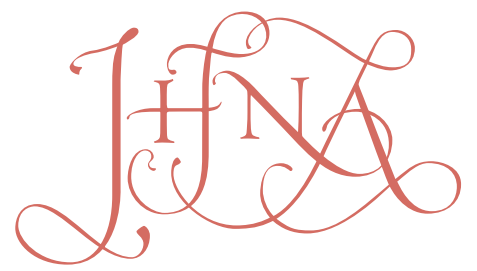

JOURNAL OF HISTORIANS OF NETHERLANDISH ART

\section{REMBRANDT'S PHILOSOPHER: ARISTOTLE IN THE EYE OF THE BEHOLDER}

\section{Menno Jonker}

One of the most intriguing commissions of a painting by Rembrandt came from Antonio Ruffo in 1653 (now in New York, Metropolitan Museum of Art). This article analyzes the contradictory identifications of the subject of this work, from the very moment it arrived in Messina. With a novel focus on three layers of intrinsic and contextual information that are fundamental to identify the figure, it concludes that Rembrandt did not depict Aristotle or Albertus Magnus or any other historical figure, but instead the universal philosopher. D0I: 10.5092/jhna.2017.9.1.12

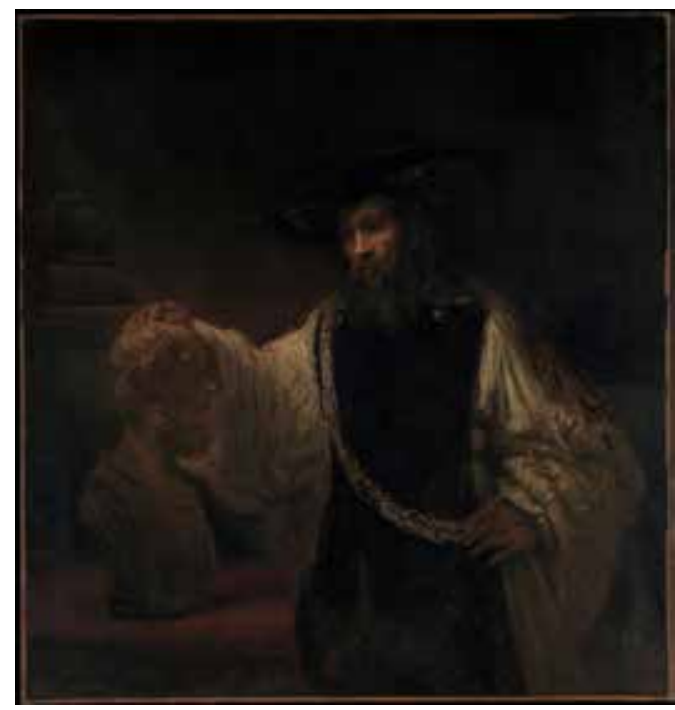

Fig. 1 Rembrandt van Rijn, Aristotle with a Bust of Homer (here identified as The Philosopher), 1653, oil on canvas, $143.5 \times 136.5 \mathrm{~cm}$. New York, The Metropolitan Museum of Art, inv. 61.198 (artwork in the public domain)

"To me this is one of the monuments of Western culture. We have Aristotle as a philosopher with a central, moral problem of human experience. We see Aristotle in his late years and he is thinking, will I be remembered like I remember Homer? Material things, honor, fame, so what? Did I say anything important?"

With this poetic statement, made in 2013, Walter Liedtke professed his reverence for the painting 
by Rembrandt van Rijn (1606-1669). Indeed, the work, made in 1653, is not a customary depiction of a classical philosopher (fig. 1). Rembrandt made use of "modern-day" dress and added particular attributes, highly unusual both in the Netherlands-where it was created-and also in Spanish Sicily, where it was commissioned. In fact, the portrait is so curious that it casts into doubt the very identification of the subject as Aristotle. This uncertainty is further exacerbated by the fact that even the commissioner of the portrait was uncertain about who was ultimately represented in the painting.

2 In this article, I will analyze the Sicilian commission of Rembrandt's painting and the various identifications of the figure that have been made, from the earliest sources into the present. A new question that presents itself is how the perception of the figure in Messina can be equated with the perception of classical philosophers in Amsterdam, and on what level the latter is applicable to Rembrandt's choice of subject. In that respect, Rembrandt would have been informed by Spanish artists' - in particular Ribera's-handling of classical philosophers, which was so fundamentally different from the standards in the Netherlands. With a new focus on three layers of information that are crucial to the identification of the subject (Ruffo's autonomous request for a figure in 1653; the link between Rembrandt's three paintings for Ruffo; and the context of Ruffo's series of seven paintings), my conclusion is that Rembrandt depicted not Aristotle in particular, as has generally been stated, but rather the universal image of the philosopher.

\section{Ruffo's Commission}

Very soon after Rembrandt's painting arrived at its destination in 1654, it was described as a halflength figure of a philosopher made in Amsterdam by the painter Rembrandt, probably representing Aristotle or Albertus Magnus. ${ }^{2}$ The owner was Antonio Ruffo (1610/11-1678), a wealthy aristocrat who owned a palace in the city of Messina on the island of Sicily, then under Spanish rule. He collected paintings from various artists from all over Europe; his inventory lists works by Titian, Ribera, Poussin, Dürer, and Rubens.

The note referenced above gives a rare and crucial insight into how Rembrandt's painting was perceived at the time. Unfortunately, the only documents to this effect that remain are from Ruffo's milieu, so we can only wonder as to Rembrandt's intentions. Some of the information in this 1654 note triggers specific questions: first, did Ruffo request a half-length figure of any type, or did he expressly ask for a philosopher? ${ }^{4}$ And second, more importantly, why did conspicuous confusion about the identification given in Ruffo's inventories persist for more than a century (see table 1) $?^{5}$ Saying that the figure could be Aristotle or Albertus Magnus is like saying he could be Galileo Galilei or Stephen Hawking. In other words: Ruffo had no clue. So what happened here?

Table 10 verview of the different identifications of the figure in Rembrandt van Rijn's painting, Aristotle with a Bust of Homer (here identified as The Philosopher)

$\begin{array}{lll}\text { Year } & \text { Name } & \text { Identification } \\ 1654 & \text { Van Goor } & \text { Painting }\end{array}$




\begin{tabular}{|c|c|c|}
\hline 1654 & Inventory Ruffo & Philosopher: Artistotle or Albertus Magnus \\
\hline 1657 & Note Ruffo & Albertus Magnus \\
\hline 1660 & Letter Guercino & Half-length figure \\
\hline 1660 & Letter Guercino & Physiognomist \\
\hline 1661 & Letter Pretti & Half-length figure \\
\hline 1662 & Letter Van Hol & Aristotle \\
\hline $1668-77$ & Inventory Ruffo & Albertus Magnus or Aristotle \\
\hline $1668-77$ & Inventory Ruffo & Aristotle or Albertus Magnus \\
\hline 1670 & Letter Brueghel & Half-length figure \\
\hline 1671 & Brandi & Painting \\
\hline 1678 & Inventory Ruffo & Aristotle \\
\hline 1689 & Inventory Ruffo & Aristotle \\
\hline 1710 & Inventory Ruffo & Aristotle or Albertus Magnus \\
\hline 1783 & Inventory Ruffo & Albertus Magnus \\
\hline 1810 & Auction Christie's & Sculptor \\
\hline 1815 & Catalogue London & Pieter Cornelisz Hooft \\
\hline 1824 & Nicol & Pieter Cornelisz Hooft \\
\hline 1836 & Smith & Pieter Cornelisz Hooft \\
\hline $1838 / 54$ & Waagen & Pieter Cornelisz Hooft \\
\hline 1877 & Vosmaer & Pieter Cornelisz Hooft \\
\hline 1883 & Von Bode & Portrait of a Man \\
\hline 1885 & Dutuit & Pieter Cornelisz Hooft \\
\hline 1893 & Catalogue London & Pieter Cornelisz Hooft \\
\hline 1894 & Michel & Portrait of a Man \\
\hline 1895 & Bredius and Hofstede de Groot & Portrait of a Man \\
\hline 1897 & Six & Torquato Tasso \\
\hline 1897-1906 & Von Bode & A Bearded Man \\
\hline 1900 & Von Bode & Portrait of a Scholar \\
\hline 1900 & Glück & A Dutch Poet of Scholar \\
\hline 1903 & Marguillier & A Poet or Scholar \\
\hline 1904 & Rosenberg & A Portrait of a Scholar \\
\hline 1905 & Neumann & A Man \\
\hline 1906 & Rosenberg & A Portrait of a Man of Letters / Savant \\
\hline 1907 & Von Bode & Portrait of a Savant \\
\hline 1908 & Grant & Philosopher or a Student \\
\hline 1909 & Valentiner & The Savant / Virgil \\
\hline 1909 & Kruse & Torquato Tasso \\
\hline 1910 & Waldmann & Virgil \\
\hline 1914 & Ruffo & Aristotle or Albertus Magnus \\
\hline 1915 & Schmidt Degener & A Poet / Virgil / Tasso \\
\hline 1916 & Hofstede de Groot & A Bearded Man \\
\hline 1917 & Hoogewerff & Aristotle \\
\hline 1918 & Ricci & Aristotle \\
\hline
\end{tabular}




\begin{tabular}{|c|c|c|}
\hline 1919 & Ruffo & Aristotle \\
\hline 1923 & Meldrum & Portrait of a Man of Letters \\
\hline 1924 & Neumann & Aristotle \\
\hline 1925 & Backer & Aristotle \\
\hline 1928 & Exhibition London & A Savant \\
\hline 1929 & Washburn Freund & Aristotle \\
\hline 1930 & Exhibition Detroit & Aristotle \\
\hline 1935 & Bredius & Aristotle \\
\hline 1947 & Mahon & Aristotle \\
\hline 1953 & Slive & Aristotle \\
\hline 1956 & Benesch & Aristotle \\
\hline 1957 & Saxl & Aristotle \\
\hline 1962 & Rousseau & Aristotle \\
\hline 1968 & Emmens & Aristotle \\
\hline 1969 & Bredius & Aristotle \\
\hline 1969 & Gerson & Aristotle \\
\hline 1969 & Held & Aristotle \\
\hline 1976 & Valentiner & Aristotle \\
\hline 1984 & Deutsch Carroll & Aristotle \\
\hline 1984 & Schwartz & Aristotle \\
\hline 1986 & Tümpel & Aristotle \\
\hline 1995 & Giltaij & Aristotle \\
\hline 1995 & Von Sonnenberg, et. al. & Aristotle \\
\hline 1997 & Giltaij & Aristotle \\
\hline 2002 & Golahny & Aristotle \\
\hline 2003 & De Gennaro & Aristotle \\
\hline 2004 & Liedtke & Aristotle \\
\hline 2005 & Giltaij & Aristotle \\
\hline 2005 & Van de Wetering & Aristotle \\
\hline 2006 & Crenshaw & Aristotle or Apelles \\
\hline 2006 & Moormann & Aristotle \\
\hline 2006 & De Winkel & Aristotle \\
\hline 2007 & Liedtke & Aristotle \\
\hline 2014 & Bikker & Aristotle \\
\hline 2016 & Sheers Seidenstein & Aristotle \\
\hline
\end{tabular}

5 We can assume that Ruffo had not asked for a specific philosopher, or he would not have had to guess. Considering other commissions made by the patron, it was more or less his practice to be non-specific. But if Rembrandt were only asked for a half-length figure, then looking at his oeuvre, with its many biblical figures, wouldn't it be more reasonable to suspect an apostle or a saint? There is only one other philosopher known by Rembrandt, which is mentioned in a collection in The Hague in 1752. This piece, which is overlooked in the literature, is called a life-sized threequarter-length figure (kniestuk), a description that would have been suitable for the painting in 
the Metropolitan Museum's collection as well. ${ }^{6}$ Most likely this was a type of general philosopher similar to the one ordered by Ruffo. It makes sense that Ruffo would have commissioned a philosopher by giving hints as to his wishes to the two mediators of this transaction, Giacomo di Battista in Messina and Cornelis Gijsbertz van Goor in Amsterdam. ${ }^{7}$ But Rembrandt clearly made it difficult to identify the picture.

The current title of the painting, Aristotle with the Bust of Homer, raises some questions with regard to Ruffo's understanding of the painting. It is hard to believe that this classical bust originally would have been mistaken as anything but the image of the famous poet. After all, the particularities of a blind man with a headband as identifying Homer could be seen even in seventeenth-century illustrated encyclopedias. ${ }^{8}$ However, evidence that the bust was not recognized as Homer lies again in the confusion regarding the identification. ${ }^{9}$ The classical Greek Aristotle and the thirteenth-century Albertus Magnus-who studied and worked in Cologne, Paris, Padua, and Bologna among other cities-shared a common interest: the natural sciences. ${ }^{10}$ Therefore, the two figures do share a connecting thread and if the bust had been clearly recognized by Ruffo as the image of Homer, then there would have been no logical reason to match it with Albertus Magnus. ${ }^{11}$ Aristotle shares a more obvious connection to Homer, although he certainly has no exclusive rights to a relationship with the poet. ${ }^{12}$

7 During the nineteenth and early twentieth centuries, the question as to whether the portrait featured Aristotle or Albertus Magnus seems to have been forgotten. Leaving aside the classical bust, various writers have found the leading clues to the philosopher's identity in the figure's clothing, which is a mixture of "classical" white drapery, an invented black sleeveless tunic, and a sixteenth-century hat of the sort that was also worn by seventeenth-century scholars. ${ }^{13}$ This combination resulted in alternative identifications of the figure as Virgil, Torquato Tasso, or, a figure even closer to Rembrandt's own time, Pieter Cornelisz Hooft (see table 1). Some authors did not wish to burn their hands on a false identification and titled the work merely as a "savant" or a portrait of a scholar or a bearded man (of letters). From 1929 on, however, only one of the two original identifications continued to be associated with the picture. Since then, Rembrandt's figure has been consistently identified as Aristotle. To see if this is justified, let us take a closer look at the image of this philosopher.

\section{The Image of Aristotle}

8 Contrary to what might be expected, Aristotle-despite being one of the most famous philosophers-is quite absent from seventeenth-century painting. This is particularly noteworthy in the Netherlands, where anecdotes about classical thinkers were (literally) popular. Owing to the rise of easily accessible commonplace and emblem books in the vernacular, nonacademic readers were able to read (and view) stories of Alexander the Great visiting Diogenes or of Hippocrates diagnosing Democritus. Joost van den Vondel's Gulden Winckel (Amsterdam, 1613), for example, includes many philosophical praatjes bij plaatjes (conversation pictures). Plato and Socrates play a small role in his book, but Aristotle never once appears. ${ }^{14}$

9 So how did the seventeenth-century art lover recognize the philosophorum princeps? A strong possibility is through illustrated encyclopedic overviews. In André Thevet's Les vrais pourtraits et 


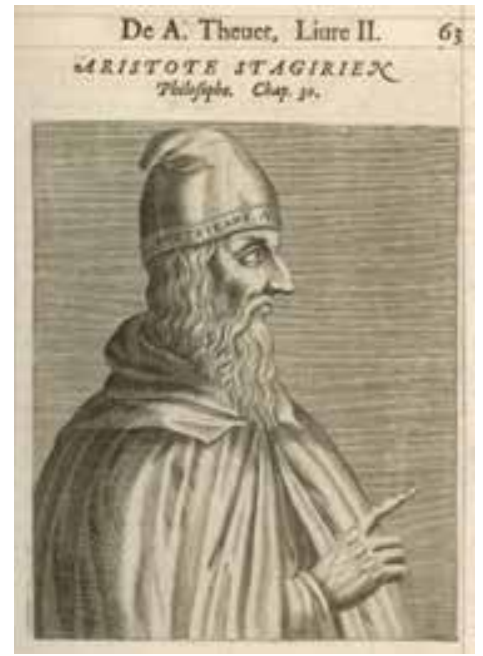

Fig. 2 Anonymous, Aristotle, print, from André Thevet, Les vrais pourtraits et vies des hommes illustres (Paris, 1584), p. 63 (artwork in the public domain)

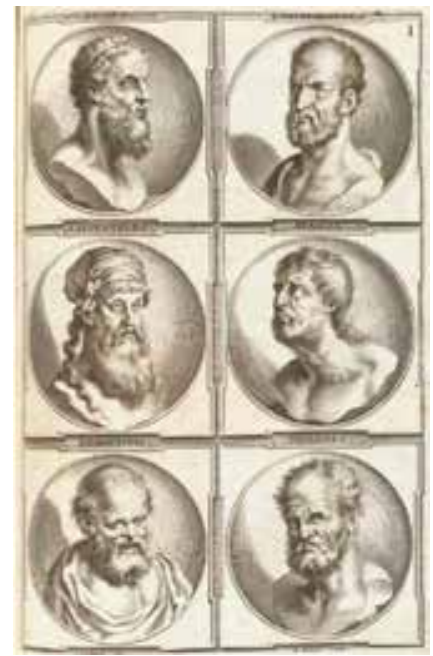

Fig. 4 Bartholomäus Kilian II, after Joachim von Sandrart, Plato, Theophrastus, Aristotle, Seneca, Democritus, Diogenes, print, from Joachim von Sandrart, Academia todesca delia architectura, scultura e pittura: Oder Teutsche Academie der Edlen Bau-Bild- und Mahlerey-Künste. . (Nuremberg, 1675-80) (artwork in the public domain)

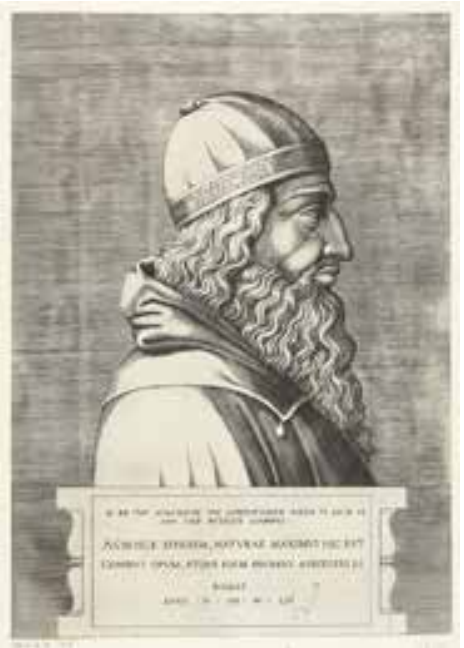

Fig. 3 Cornelis Bos (possibly), after Enea Vico, Aristotle, ca. 1530-ca. 1560, engraving. Amsterdam, Rijksmuseum, inv. RP-P-H-H-1125 (artwork in the public domain)

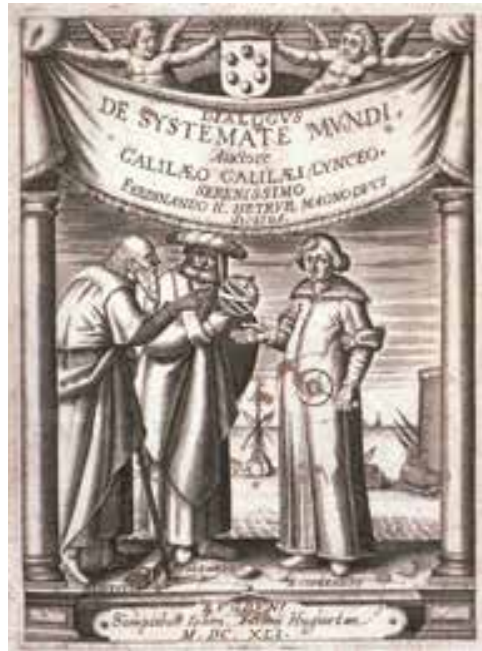

Fig. 5 Anonymous, Aristotle, Ptolemy, and Copernicus, frontispiece, from Galileo, Dialogus de Systemate Mundi (Leiden, 1641) (artwork in the public domain)

vies des hommes illustres (1584), Aristotle is depicted en profil with long curly hair, a long beard, a hat, and a cape (fig. 2). ${ }^{15}$ This type - with or without an elevated hand-was characteristic for both the Middle Ages and the early modern period and was also circulated in separate prints by engravers such as Enea Vico (1523-1567) (fig. 3). Another type of depiction was as a beardless youth derived from an en profil relief, which is known from a print in Fulvio Orsini's Imagines et elogia vivorum illustrium (Rome, 1570). ${ }^{16}$ Thirdly, as can be seen in a drawing by Theodoor Galle (made after a bust), Aristotle is shown with short hair and a short beard. ${ }^{17}$ Another bust lookalike was included in Joachim von Sandrart's famous compilation of 1675-80, Academia todesca delia architectura, scultura e pittura: in a set of six medallions, Aristotle is depicted with a long beard, loose locks of hair, and a linen head cover (fig. 4). In frontispieces we find a fifth variant, 
with Aristotle as a bald-headed graybeard (fig. 5). Given this broad spectrum, it would have been relatively important to add Aristotle's name to a title or description of a work to identify him.

10 From natural history to astronomy, from rhetoric to poetics, the reception of Aristotle was shaped by many disciplines, but the tendency to question the authority of the philosopher was made especially urgent by new scientific approaches and experiments. Borelli was in conflict with Aristotle as a result of his research on the movements of animals; Swammerdam disagreed with the Aristotelian notion of spontaneous generation by insects; Descartes's mechanistic worldview was an explicit replacement of the older Aristotelian paradigm; and Galileo came to alternative conclusions in the lively debate on gravity. The latter was perfectly visualized in the frontispiece of a publication in 1641, with Galileo's opponents Aristotle and Ptolemy representing the old and his fellow thinker Copernicus the new (see fig. 5). ${ }^{18}$

11 In the humanities, Aristotle's ideas caused less conflict. Aristotle's Poetica continued to play a role, as evidenced in publications by Gerardus Vossius and Daniel Heinsius. Vondel, among others, was inspired by strict Aristotelean rules in theater plays. ${ }^{19}$ Aristotle was also visible in Diogenes Laertius's frequently published and translated biography of the classical philosophers. Aristotle's moralist sayings, as derived from these works, were in return used for comptoiralmanakken. ${ }^{20}$ These wise epithets were common even in the decorative arts. ${ }^{21}$ Therefore, despite a lack of (consistent) depictions of the ancient philosopher in art, and his controversial role in science, it can be assumed that Aristotle was not completely absent from the minds of the people of Amsterdam-Rembrandt included. The artist owned a bust of Aristotle and must have known about the philosopher even as a schoolboy in Leiden. ${ }^{22}$ But did this familiarity lead to the philosopher's depiction?

\section{Rembrandt's Choice}

12 As argued above, it is logical to assume that Ruffo specifically requested that Rembrandt paint a philosopher (and not just a half-length figure). ${ }^{23}$ The result, however, was not a response to popular philosophical themes in the Netherlands at the time. Only a year prior, Caesar van Everdingen had depicted the popular story of Diogenes and Alexander the Great at a market. ${ }^{24}$ In his own early years Rembrandt was inspired by the Caravaggesque movement in Utrecht and was therefore aware of the frequently depicted pendants of the laughing Democritus and crying Heraclitus, as well as the more stoic image of the dying Seneca. His own teacher, Pieter Lastman, depicted Hippocrates visiting Democritus in $1622 .{ }^{25}$ But Rembrandt chose none of these for the subject of his painting.

13 Instead, Rembrandt must have investigated or been in some way aware of the Spanish approach to representing philosophers. One particular artist is noteworthy here: Jusepe de Ribera (15911652). His work, an example of which Ruffo bought in 1647, was also to be found in Amsterdam collections from 1639 onward: Gysbert van Goor (son of Rembrandt's agent Cornelis Gijsbertz van Goor) and Rembrandt's relative by marriage, Gerrit Uylenburgh, owned paintings by Ribera; the latter even owned a painting of a philosopher. ${ }^{26}$ Ribera, known in the North as Spanjolet, was famous for a series of philosophers that were put into print by Bernard Vaillant. Vaillant made, for example, a reversed mezzotint of a philosopher that was once entitled Aristotle-defining the 


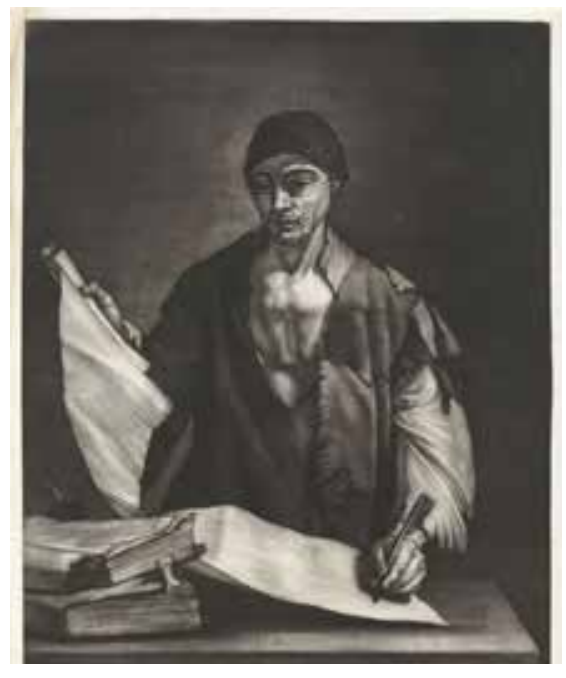

Fig. 6 Bernard Vaillant, after Jusepe de Ribera, Philosopher, 1672, mezzotint. Amsterdam, Rijksmuseum, inv. RP-P1982-54 (artwork in the public domain)

precise subject is difficult in many of these unspecified images of classical thinkers (fig. 6). ${ }^{27}$ This series was produced in 1672 and could therefore not have been seen by Rembrandt. He did, however, own a boeck with (reproductions of) Ribera's etchings. ${ }^{28}$ We do not know if this "book"likely a bound compilation of prints - contained philosophers, but the well-known Southern formula of a life-sized isolated man in a dark room, standing at a table with books, papers, pens, or specific scientific tools, appears to be more of a prototype for Rembrandt's figure than the Northern tradition of depicting the philosopher in an active interaction with other people, often situated outdoors.

14 Yet Ribera's type was not entirely sufficient as a model for Rembrandt's philosopher. Rembrandt ignored the beggars' tatters typically worn by the Spanish artist's subjects. Instead, he chose to depict the figure in a rich black and white dress, which Ruffo associated with guisa di monaco (the dress of a monk), in particular that of the Dominican order, which was the religious background of Albertus Magnus. ${ }^{29}$ Apparel consisting of white "classical" drapery, a black sleeveless tunic, a golden chain, and a hat was often used by Rembrandt and his students for unidentified scholars, but none of these attributes have anything to do with Aristotle or any other classical figure in particular. The facial characteristics are likely taken from a model and not, by contrast, from the bust of the philosopher owned by Rembrandt or other extant visual sources on Aristotle, since they have little in common with those discussed previously. ${ }^{30}$ The only telling, but small, reference to Aristotle might be the ring in his ear and the one on his finger, since this jewelry is described in textual sources, but it should be noted that Rembrandt gave such accessories to a few generic images of scholars as well. ${ }^{3}$

15 Attention must also be paid to the philosopher's arm, which is not elevated as is typical of Aristotle (see fig. 2). ${ }^{32}$ This gesture is represented most famously in Raphael's School of Athens (1509-11, Vatican), where Aristotle is shown in complement to his teacher Plato, both referring with their gestures to their own opposing philosophies of the ideal and the visible world (fig. 7). I argue, however, that Rembrandt gives his figure, with the hand resting on the sculpted head (and therefore the mind), a different pose altogether. This gesture can instead be ascribed to the ultimate image of thinking: the central activity of the philosopher. 


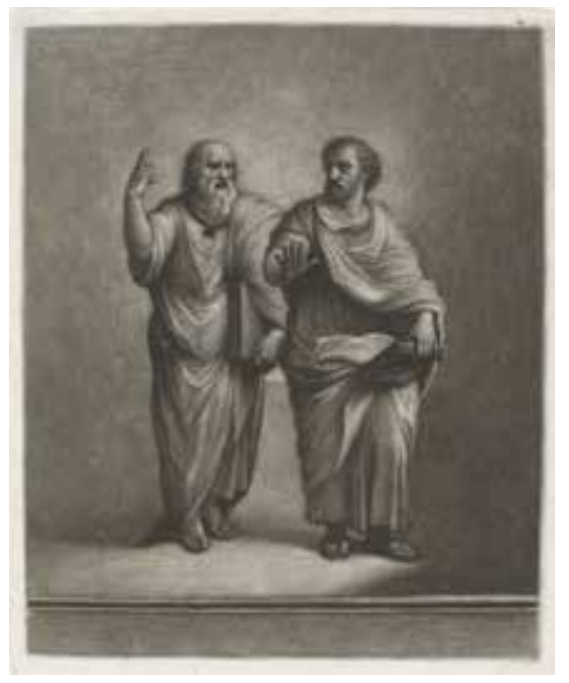

Fig. 7 Wallerant Vaillant, after Raphael, Plato and Aristotle, 1658-77, mezzotint Amsterdam, Rijksmuseum, inv. RP-P-1910-6901 (artwork in the public domain)

\section{Conclusion}

In later years Ruffo sought pendants for Rembrandt's figure and asked the seventy-year-old painter Giovanni Francesco Barbieri, called Guercino, to comply. In 1660 Guercino wrote to the nobleman that he would be honored to make a cosmographer to accompany Rembrandt's "physiognomist." Guercino based this surprising identification on a sketch made of the painting. Ruffo had said nothing more about Rembrandt's choice than to specify its size, and that Guercino's painting had to be a half-length figure. ${ }^{33}$ The description of the figure without any further reference to the content or identification can also be seen in a letter from 1661 by the artist Mattia Preti, following Ruffo's request for another work to accompany Rembrandt's painting, and again in a letter of complaint by Abraham Breughel to Ruffo in 1670 (table 1). ${ }^{34}$ They both mention only a half-length figure when referring to Rembrandt's painting. Thus it can be assumed that the content of the pendants was not Ruffo's primary concern: first and foremost they had to look good in line with one another and preferably be symmetrical when displayed together in his palace. ${ }^{35}$

17 Ruffo continued to collect by commission for this particular series, most probably with the same request: a half-length figure being more or less specified. In 1661 Rembrandt made an Alexander the Great, Mattia Preti finished a Dionysius of Syracuse in 1662, and Rembrandt's Homer arrived another year later. The desire to identify the philosopher in the work under discussion has often been connected with finding an intrinsic link with Rembrandt's latter two figures. However, the 1653 philosopher needs first and foremost to be understood as an autonomous painting: only eight to ten years later did Rembrandt create the other two. ${ }^{36}$ From Ruffo's perspective this addition was to complement his series of half-figures executed by the great masters of his time. From Rembrandt's perspective he was only aware of the paintings that he himself had made for the collection. So in a way, it is justified to retrospectively search for a link among the three. Indeed, Alexander and Homer can be combined with Aristotle, as was done by the shipmaster Nicolaes van $\mathrm{Hol}$ in an addition to the receipt for the latter two works in 1662 (see table 1). ${ }^{37}$ However, this combination is only known in textual sources such as Plutarch. ${ }^{38}$ The combination of the three is simply absent in art. 
18 More important and neglected over time is the evidence that Ruffo continued to question the identity of the philosopher (see table 1) and ignored a unique link with the other two paintings as well. ${ }^{39} \mathrm{He}$ proceeded to expand the series with an Archita Tarantino done by Salvator Rosa in 1668 and finally a painting sent by Giacinto Brandi in 1670, which was defined as the philosopher or as Saint Jerome-another proof that Ruffo struggled, or didn't particularly care, to expressly define the subject matter. Considering the broad range of this series, it is hard to believe that Ruffo's commissions were content driven, and Rembrandt's three paintings therefore should not be seen with a privileged meaning. In short, there are three layers of information that can be considered in an effort to define Rembrandt's philosopher: Ruffo's autonomous request for a painting made in 1653; the link between Rembrandt's three paintings; and the context of Ruffo's series of seven paintings. Trying to find evidence for the identification of Aristotle, as scholars have done from the early twentieth century until now, means a focus only on step two and neglects several key aspects. This ignores the idiosyncrasies of the figure of the philosopher, its iconographic elements, and the place of the commission in the context of all the paintings displayed in Ruffo's palace.

19 Finally, to return to what is actually depicted by Rembrandt, neither the identification of the bust nor the figure on the medal attached to the philosopher's chain appears to play a specific role in documents from Ruffo's time. ${ }^{40}$ Yet Rembrandt incorporated these classical attributes on purpose. Without these elements the figure is merely a seventeenth-century scholar or-if one prefers-a Dominican scientist like Albertus Magnus. ${ }^{41}$ At the same time, however, these elements are not sufficient evidence to lead to an exclusive association with a specific philosopher from the classical period, such as Aristotle. The result, as depicted by Rembrandt, provides instead the universal image of the philosopher.

20 The intricate manner of depiction, and the space it leaves for such a case of mistaken identity, compels me to fully identify with Walter Liedtke, who described the painting as follows: "There is more packed into the meaning than usual in a Rembrandt, but I am drawn to it initially because it is compelling. I sort of got it in my gut or my heart." 42

\section{Acknowledgements}

I am grateful to the editors Stephanie Dickey and Alison M. Kettering, the anonymous reviewer, and the copyeditor Cynthia Newman Edwards for their comments. Many thanks in particular to my research promoter Volker Manuth, to Pieter Roelofs and Marieke de Winkel, and to Angela Bartholomew for patiently correcting my English. Writing art history is only satisfying thanks to the help of my friends and colleagues.

Menno Jonker is an independent curator and researcher. His exhibition and research projects consider the depiction of Asian, African and American culture and nature in early modern art and science (Kunsthal Rotterdam, Staatliche Kunstsammlungen Dresden, Rijksmuseum Amsterdam, Peabody Essex Museum, Frans Hals Museum) and fashion in art and costume history (Museum Het Valkhof, Rijksmuseum Amsterdam). The topic of his PhD thesis is the perception of classical philosophers in art and science of the seventeenth-century Netherlands (Radboud University).

info@mennojonker.nl 


\section{List of Illustrations}

Table 1 Overview of the different identifications of the figure in Rembrandt van Rijn's painting, Aristotle with a Bust of Homer (here identified as The Philosopher)

Fig. 1 Rembrandt van Rijn, Aristotle with a Bust of Homer (here identified as The Philosopher), 1653, oil on canvas, 143.5 x $136.5 \mathrm{~cm}$. New York, The Metropolitan Museum of Art, inv. 61.198 (artwork in the public domain)

Fig. 2 Anonymous, Aristotle, print, from André Thevet, Les vrais pourtraits et vies des hommes illustres (Paris, 1584), p. 63 (artwork in the public domain)

Fig. 3 Cornelis Bos (possibly), after Enea Vico, Aristotle, ca. 1530-ca. 1560, engraving. Amsterdam, Rijksmuseum, inv. RP-P-H-H-1125 (artwork in the public domain)

Fig. 4 Bartholomäus Kilian II, after Joachim von Sandrart, Plato, Theophrastus, Aristotle, Seneca, Democritus, Diogenes, print, from Joachim von Sandrart, Academia todesca delia architectura, scultura e pittura: Oder Teutsche Academie der Edlen Bau-Bild- und Mahlerey-Künste ... (Nuremberg, 1675-80) (artwork in the public domain)

Fig. 5 Anonymous, Aristotle, Ptolemy, and Copernicus, frontispiece, from Galileo, Dialogus de Systemate Mundi (Leiden, 1641) (artwork in the public domain)

Fig. 6 Bernard Vaillant, after Jusepe de Ribera, Philosopher, 1672, mezzotint. Amsterdam, Rijksmuseum, inv. RP-P-1982-54 (artwork in the public domain)

Fig. 7 Wallerant Vaillant, after Raphael, Plato and Aristotle, 1658-77, mezzotint Amsterdam, Rijksmuseum, inv. RP-P-1910-6901 (artwork in the public domain)

1 [Metropolitan Museum of Art], The Choice / Walter Liedtke: http://82nd-and-fifth.metmuseum. org/the-choice, accessed on June 12, 2016.

2 "1654 a 1 settembre - Rembrant - Palmi 8 e 6 - Mezza figura d'un filosofo qual si fece in Amsterdam dal pittore nominato il Rembrant (pare Aristotele o Alberto Magno)." See Jeroen Giltaij, Ruffo en Rembrandt: Over een Siciliaanse verzamelaar in de zeventiende eeuw die drie schilderijen bij Rembrandt bestelde (N.p., 1997), 36; Walter A. Liedtke, Dutch Paintings in the Metropolitan Museum of Art (New York: The Metropolitan Museum of Art/New Haven: Yale University Press, 2007), 2: 630 and 635.

${ }^{3}$ Christian Tümpel, Rembrandt (Antwerp: Mercatorfonds, 1986), 361; Walter Liedtke, “The Meaning of Rembrandt's Aristotle with a Bust of Homer," in Collected Opinions: Essays on Netherlandish Art in Honour of Alfred Bader, ed. Volker Manuth and Axel Rüger (London: Paul Holberton, 2004), 75.

${ }^{4}$ As discussed, for instance, by Liedtke, "The Meaning of Rembrandt's Aristotle with a Bust of Homer," 76.

${ }^{5}$ The information in this table is derived from C. Ricci, Rembrandt in Italia (Milan: Alfieri and 
Lacroix, 1918); Gary Schwartz, Rembrandt: Zijn leven, zijn schilderijen; Een nieuwe biografie met alle beschikbare schilderijen in kleur afgebeeld (Maarssen: Gary Schwartz, 1984); Tümpel, Rembrandt, 1986; Giltaij, Ruffo and Rembrandt, 1997; Rosanna De Gennaro, Per il collezionismo del Seicento in Sicilia: L'inventario di Antonio Ruffo Principe della Scaletta (Pisa: Scuola normale superiore, 2003); Liedtke, “The Meaning of Rembrandt's Aristotle with a Bust of Homer"; Jeroen Giltaij, "Nieuws omtrent Ruffo en Rembrandt," Kroniek van het Rembrandthuis 1-2 (2005): 46-49; Liedtke, Dutch Paintings, 646-53 (references); and the online catalogue entry, www.metmuseum. org/ collection/the-collection-online/ search/437394, accessed on June 12, 2016. From 1930 on the table contains only a selection of scholars.

6 "Een Philosooph, leevens groote, door Rembrand, schoon geschildert, zynde een Kniestuk." See Gerard Hoet, Catalogus of naamlyst van schilderyen, met derzelver pryzen zedert een langen reeks van jaaren zoo in Holland als op andere plaatzen in het openbaar verkogt, vol. 2 (The Hague: Pieter Gerard van Baalen, 1752), Graaf van Hogendorp, inv. 155, p. 307. The whereabouts of this painting are unknown. The 1653 painting is almost a kniestuk. Suggestions have been made that the painting has been trimmed; see a photographic reconstruction of the painting with missing strips at the bottom and sides in Hubert von Sonnenburg, Walter Liedtke, Carolyn Logan, Nadine M. Orenstein, and Stephanie S. Dickey, eds., Rembrandt/Not Rembrandt in the Metropolitan Museum of Art: Aspects of Connoisseurship (New York: Metropolitan Museum of Art, 1995), 1:59. Giltaij disagrees with the idea that the painting has been cut down; see Giltaij, "Nieuws omtrent Ruffo en Rembrandt," 49; Liedtke, Dutch Painting, 629, notes cusping on all four sides. Incidentally, copies of two prints of male figures by Jan van Vliet after Rembrandt made for the French and Italian public bear added descriptions that identify the figure as Aristotle in one case and Democritus in the other. Due to his close contact with van Vliet, Rembrandt must have been aware of this reidentification. Obviously, the prints have nothing in common with Rembrandt's painting of 1653. See Jaco Rutgers, "Rembrandt in Italië: Receptie en verzamelgeschiedenis" (PhD diss., University of Utrecht, 2008), 12.

${ }^{7}$ See also Ernst van de Wetering, ed., A Corpus of Rembrandt Paintings, Part 4: The Self-Portraits (Dordrecht: Springer, 2005), 339; Giltaij in von Sonnenburg et al., Rembrandt/Not Rembrandt, 2: 66-68.

${ }^{8}$ For instance, André Thevet, Les vrais pourtraits et vies des hommes illustres Grecz, Latins, et payens recueilliz de leur tableaux, livres, medalles antiques \& modernes . . (Paris, 1584); Joachim von Sandrart, Academia todesca delia architectura, scultura e pittura: Oder Teutsche Academie der Edlen Bau-Bild-und Mahlerey-Künste . . . (Nuremberg, 1675-80). For Homer in (seventeenth-century) art, see Eric M. Moormann, “The man who made the song was blind': Representations of Homer in Modern Times I," Pharos: Journal of the Netherlands Institute in Athens 12 (2004): 129-50; Eric M. Moormann, “There is a triple sight in blindness keen': Representations of Homer in Modern Times II," in Land of Dreams: Greek and Latin Studies in Honour of A. H. M. Kessels, ed. A. P. M. H. Lardinois, M. G. M. van der Poel, and V. J. C. Hunink, 229-56. (Leiden and Boston: Brill, 2006).

${ }^{9}$ See Liedtke, “The Meaning of Rembrandt's Aristotle with a Bust of Homer, 77-78; Liedtke, Dutch Paintings, 629, 635, 638. The bust is mentioned only a few times but never with a specific identification; for Ruffo's inventory of 1678 and 1689, see Giltaij, Ruffo en Rembrandt, 97-98; Giltaij, "Nieuws omtrent Ruffo en Rembrandt," 48.

${ }^{10}$ His Opera omnia dealt with physics, astronomy, and the animal world; see Albertus Magnus, Opera omnia, ed. P. Jammy, 21 vols. (Lyon, 1651). 
${ }^{11}$ In his zoological work Albertus Magnus was a follower of Aristotle; see Karl A. E. Enenkel, “The Species and Beyond: Classification and the Place of Hybrids in Early Modern Zoology," in Zoology in Early Modern Culture: Intersections of Science, Theology, Philology, and Political and Religious Education, ed. Karl A. E. Enenkel and Paul J. Smith, 57-148 (Leiden and Boston: Brill, 2014), 60, http://dx.doi.org/10.1163/9789004279179 004. The two were also painted by Justus of Ghent (ca. 1430-ca. 1480) in a series of scholars (for the Aristotle, now in the Musée du Louvre, see Liedtke, Dutch Paintings, 637, fig. 165).

${ }^{12}$ Besides Aristotle, many other classical philosophers were connected with Homer; see Diogenes Laërtius, Leven en leer van beroemde filosofen, trans. and annotated Rein Ferwerda (Budel: Damon, 2008): Anaxagoras, 2.11; Socrates, 2.21; Menedemus, 2.133; Plato, 3.5; 3.7; Xenocrates, 4.9; Aristotle, 5.5; 5.9; Demetrius, 5.81; Antisthenes, 6.17; Diogenes, 6.52; 6.53; Crates, 6.90; Empedocles, 8.57; and Democritus, 9.48.

${ }^{13}$ With thanks to Marieke de Winkel.

${ }^{14}$ See Joost van den Vondel, Den Gulden Winckel der Konstlievende Nederlanders. Gestoffeert met veel treffelijcke historische, Philosophische, Poeetische morale ende schriftuerlijcke leeringen. Geciert met schoone kunstplaten oft Beeldenissen. Vermakelyck en stichtelijck voor alle staten van Menschen (Amsterdam: Dirck Pietersz, 1613). The only applicable scene featuring Aristotle, in which the seductive Phyllis rides on his back, was a medieval and Renaissance legend.

${ }^{15}$ See Thevet, Les vrais pourtraits.

${ }^{16}$ These Aristotle types have been discussed in Menno Jonker, "Boselli's Philosophers Identified as Socrates and Plato," Rijksmuseum Bulletin 59, no. 2 (2011): 174-82. The bust of Aristotle mentioned in Rembrandt's inventory might have been one of the latter two. Margaret Deutsch Carroll describes three types of Aristotle, see Margaret Deutsch Carroll, "Rembrandt's Aristotle: Exemplary Beholder," Artibus et Historiae 5, no. 10 (1984): 43-44n25, and 55, http://dx.doi. org/10.2307/1483193.

${ }^{17}$ Theodoor Galle, Bust of Aristotle, drawing, Rome, Vatican Library.

${ }^{18}$ Volker R. Remmert, “Docet parva pictura, quod multae scripturae non dicunt': Frontispieces, Their Functions, and Their Audiences in Seventeenth-Century Mathematical Sciences," in Transmitting Knowledge: Words, Images, and Instruments in Early Modern Europe, ed. Sachiko Kusukawa and Ian Maclean (Oxford: Oxford University Press, 2006), 250-55. However, there were still conservative professors who taught Aristotle's physics and biology, for instance in Deventer; see A. A. M. de Haan, "Geschiedenis van het wijsgerig onderwijs te Deventer," in Deventer denkers: De geschiedenis van het wijsgerig onderwijs te Deventer, ed. H. W. Blom, H. A. Krop, and M. R. Wielema (Hilversum: Verloren, 1993), 43-44, 66.

${ }^{19}$ See Fritz Saxl, "Rembrandt and Classical Antiquity," in Seventeenth Century Art in Flanders and Holland, ed. J. S. Ackerman et al., Garland Library of the History of Art 9 (1957; New York and London: Garland Publishing, 1976), 200; Julius Held, Rembrandt's Aristotle and Other Studies, 2nd ed., Rembrandt Studies (1969; Princeton: Princeton University Press, 1991), 33-34; Jan Bloemendal, Spiegel van het dagelijks leven? Latijnse school en toneel in de noordelijke Nederlanden in de zestiende en de zeventiende eeuw (Hilversum: Verloren, 2003), 31; Cor Rademaker, "Wetenschappelijke handboeken die groot nieuws waren," in Orbis doctus, 1500-1850: Perspectieven op de geleerde wereld van Europa; Plaatsen en personen; Opstellen aangeboden aan professor dr. J. A. H. Bots, ed. G. C. A. M. van Gemert, F. J. M. Korsten, P. J. A. N. Rietbergen, and J. J. V. M. de Vet (Amsterdam and Utrecht: APA-Holland Universiteits Pers, 2005), 251; M. A. Schenkeveld-van der Dussen, Nederlandse literatuur in de tijd van Rembrandt (Utrecht: Bijleveld, 1994), 67 and 160. 
For Vondel, see Eric Jan Sluijter, "Rembrandt's Portrayal of the Passions and Vondel's 'staetveranderinge," in The Passions in the Arts of the Early Modern Netherlands, ed. Stephanie S. Dickey and Herman Roodenburg, special issue, Nederlands Kunsthistorisch Jaarboek 60 (2010): 285-305.

${ }^{20}$ From 1633 the popular Amsterdam Comptoiralmanak contained a selection of the "Guldene annotatien" by Franciscus Heerman, which referred to many classical philosophers; see also Jeroen Salman, Populair drukwerk in de Gouden Eeuw: De almanak als lectuur en handelswaar (Zutphen: Walburg Pers, 1999), 195. Citations were usually taken from Diogenes Laërtius's biographies and resulted in low-profile books like Diogenes Laërtius, Kort begrijp van Diogenes Laërtius zijnde het leven, heerlijke spreuken, loffelijke daden, en snedige antwoorden der oude philosophen: waar by komen eenige treffelijke spreuken en gelykenissen: uyt verscheyden heydensche en andere schryvers, selected by Paschier de Fijne (Rotterdam: Joannes Naeranus, 1655).

${ }^{21}$ In Amsterdam Hillebrant Bentes owned, until his death in 1652, a plate with an adage from Aristotle; see the death inventory of Hillebrant Bentes and his wife Catharina Baeck, 1655 (Montias 348): http://research.frick.org/montias/home.php.

${ }^{22}$ A bust of Aristotle is mentioned in the 1656 inventory of Rembrandt's insolvent estate: remdoc. huygens.knaw.nl/\#/ document/remdoc/e12719, accessed on June 12, 2016. About Rembrandt and the Leiden Latin School, see Wilhelm R. Valentiner, "Rembrandt at the Latin School," in Seventeenth Century Art in Flanders and Holland, ed. J. S. Ackerman et al., Garland Library of the History of Art 9 (New York and London: Garland Publishing, 1976), 123-24.

${ }^{23}$ Opposed by Liedtke, Dutch Paintings, 629, 633.

${ }^{24}$ Caesar van Everdingen, Diogenes Looking for an Honest Man, 1652, The Hague, Mauritshuis, inv. 39. The title "Diogenes in a Dutch market" would be more suitable since several moments of Diogenes's life are visualized in the context of a Dutch seventeenth-century market, like his remarkable meeting with Alexander the Great.

${ }^{25}$ Pieter Lastman, Hippocrates Visiting Democritus, 1622, Lille, Palais des Beaux-Arts.

${ }^{26}$ In 1647 Ruffo obtained four half-length saints by Ribera; see Delphine Fitz Darby, "Ribera and the Wise Men," Art Bulletin 44, no. 4 (1962): 303, http://dx.doi.org/10.1080/00043079.1962. 10789059. Several works by Ribera have been found in seventeenth-century collections in the Northern Netherlands (including those of Van Goor and Uylenburgh); see Mariska Dekker, Vergeten Spaanse meesters: Zeventiende-eeuwse Spaanse kunstwerken in de Noordelijke Nederlanden tussen 1617-1800, MA thesis, Vrije Universiteit Amsterdam, 2014, 15, 17, 159-166. Uylenburgh owned two works, one mentioned in 1675 as "Een philosoph van Spanjolet"; see Friso Lammertse and Jaap van der Veen, Uylenburgh \& Zoon: Kunst en commercie van Rembrandt tot De Lairesse, 1625-1675 (Zwolle: Waanders, 2006), 297.

${ }^{27}$ For Vaillant's prints after Ribera, see Els Verhaak, "Filosofen naar Spaanse voorbeelden door Bernard Vaillant: Een oeuvre wordt uitgebreid," Bulletin van het Rijksmuseum 34, no. 4 (1986): 247-55. Verhaak (p. 248) identified the figure as Aristotle, but Nicola Spinosa maintains he is simply a philosopher since there are no particular clues that lead to Aristotle; see Nicola Spinosa, Ribera (Naples: Electa, 2006), 294. Darby wrote that Rembrandt followed Ribera's modus operandi in general, Darby, "Ribera and the Wise Men," 303.

28 "Een dito [boeck] van ... Spanjolette," mentioned in the 1656 inventory of Rembrandt's insolvent estate, remdoc.huygens.knaw.nl/\#/document/ remdoc/e12721, accessed on June 12, 2016.

${ }^{29}$ With thanks to Volker Manuth. In 1650 Ruffo already owned another Albertus Magnus; see Giltaij, Ruffo en Rembrandt, 136. For this description of the inventory of 1668-1677, see De Gennaro, Per il collezionionismo del Seicento in Sicilia, 129; Giltaij, "Nieuws omtrent Ruffo en 
Rembrandt," 48.

${ }^{30}$ Liedtke, Dutch Paintings, 642, fig. 167, identified the figure as the same model depicted in $A$ Bearded Man in a Cap, ca. 1653/57, London, The National Gallery.

${ }^{31}$ For the rings in textual sources, see Marieke de Winkel, Fashion and Fancy: Dress and Meaning in Rembrandt's Paintings (Amsterdam: Amsterdam University Press, 2006), 210, n101. For scholars with a ring, see Rembrandt van Rijn, A Scholar in His Study, ca. 1634, Prague, Národní Galerie v Praze, inv. DO 4288; Rembrandt van Rijn, Scholar at His Writing Table, 1641, Warsaw, Zamek Królewski w Warszawie, inv. ZKW 3905.

${ }^{32}$ As suggested by Thijs Weststeijn, "De zichtbare wereld: Samuel van Hoogstratens kunsttheorie en de legitimering van de schilderkunst in de zeventiende eeuw" (PhD diss., University of Amsterdam, 2005), statement 7; de Winkel, Fashion and Fancy, 210.

${ }^{33}$ Concluding from Guercino's letters to Ruffo of June 13, 1660, August 18, 1660, and October 6, 1660; see Giltaij, Ruffo en Rembrandt, 80, 192-94. See also Tümpel, Rembrandt, 36. Even the identification of the cosmographer was not consistent, since a later inventory of 1739 speaks of Columbus instead (ibid., 104).

${ }^{34}$ For Preti's letter to Ruffo of September 18, 1661, see Giltaij, Ruffo en Rembrandt, 195. For Breughel's letter to Ruffo of January 24, 1670, see ibid., 200; see also Schwartz, Rembrandt, 308; Tümpel, Rembrandt, 375. Breughel's letters to Ruffo about Brandi's painting from November 20, 1670, and March 3, 1671, mention only "accompagnare ad une del Rymbrant" and "accompagnare quella del Rembrant"; see Giltaij, Ruffo en Rembrandt, 201.

${ }^{35}$ See also Liedtke, Dutch Paintings, 632.

${ }^{36}$ See Held, Rembrandt's "Aristotle," 26, 36.

${ }^{37}$ See Ricci, Rembrandt in Italia, 10, 13; Giltaij, Ruffo en Rembrandt, 186-89.

${ }^{38}$ For the sources, see de Winkel, Fashion and Fancy, 210. It should be noted that there is also a negative link between Aristotle and Alexander, mentioned by Samuel van Hoogstraten. "Ik ben ook niet beschreumt een bestraffing, gelijk als Aristoteles van Alexander verkreeg ... te hooren" (I am also not shy, to hear a reprimand, like Aristotle received from Alexander): Samuel van Hoogstraten, Inleyding tot de hooge schoole der Schilderkonst: anders de zichtbaere werelt (Rotterdam: François van Hoogstraten, 1678), bk. 1, p. 3. Held, Rembrandt's Aristotle, 53-54, mentions the estrangement between Alexander and Aristotle, referring to Plutarch and Diogenes Laertius. ${ }^{39}$ See also Giltaij, Ruffo en Rembrandt, 76-77.

${ }^{40}$ The en profil head on the medal can be identified as Alexander the Great or Athena, a suitable symbol of wisdom, see Abraham Bredius, Rembrandt: The Complete Edition of the Paintings, 3rd ed, rev. H. Gerson (London: Phaidon, 1969), 594; Carroll, "Rembrandt’s Aristotle," 45-46, 56n78, http://dx.doi.org/10.2307/ 1483193; Giltaij, Ruffo en Rembrandt, 41; Liedtke, Dutch Paintings, 635. The extended inventory of 1668-77 only mentions a medallion (without an identification); see Giltaij, "Nieuws omtrent Ruffo en Rembrandt," 48.

${ }^{41}$ The costume seems to be based on fashionable dress from the early sixteenth century; see de Winkel, Fashion and Fancy, 169. See also van de Wetering, Corpus of Rembrandt Paintings, 466. ${ }^{42}$ Liedtke, “The Choice" (see note 1 above), accessed on June 12, 2016.

\section{Bibliography}

Albertus Magnus. Opera omnia. Edited by P. Jammy. 21 vols. Lyon, 1651. 
Bikker, Jonathan, et al. Rembrandt: The Late Works. Exh. cat. London: National Gallery, and Amsterdam: Rijksmuseum, 2014.

Bloemendal, Jan. Spiegel van het dagelijks leven? Latijnse school en toneel in de noordelijke Nederlanden in de zestiende en de zeventiende eeuw. Hilversum: Verloren, 2003.

Bredius, Abraham. Rembrandt: The Complete Edition of the Paintings. 3rd ed. Revised by H. Gerson. London: Phaidon, 1969.

Carroll, Margaret Deutsch. "Rembrandt's Aristotle: Exemplary Beholder." Artibus et Historiae 5, no. 10 (1984): 35-56. http://dx.doi.org/10.2307/1483193

Darby, Delphine Fitz. "Ribera and the Wise Men.” Art Bulletin 44, no. 4 (1962): 279-307. http:// dx.doi.org/10.1080/00043079.1962.10789059

De Gennaro, Rosanna. Per il collezionismo del Seicento in Sicilia: L'inventario di Antonio Ruffo Principe della Scaletta. Pisa: Scuola normale superiore, 2003.

Dekker, Mariska. Vergeten Spaanse meesters: Zeventiende-eeuwse Spaanse kunstwerken in de Noordelijke Nederlanden tussen 1617-1800, MA thesis, Vrije Universiteit Amsterdam, 2014.

Diogenes Laërtius. Kort begrijp van Diogenes Laërtius zijnde het leven, heerlijke spreuken, loffelijke daden, en snedige antwoorden der oude philosophen: waar by komen eenige treffelijke spreuken en gelykenissen: uyt verscheyden heydensche en andere schryvers. Selected by Paschier de Fijne. Rotterdam: Joannes Naeranus, 1655.

Diogenes Laërtius. Leven en leer van beroemde filosofen. Translated and annotated by Rein Ferwerda. Budel: Damon, 2008.

Enenkel, Karl A. E. "The Species and Beyond: Classification and the Place of Hybrids in Early Modern Zoology." In Zoology in Early Modern Culture: Intersections of Science, Theology, Philology, and Political and Religious Education, edited by Karl A. E. Enenkel and Paul J. Smith, 57-148. Leiden and Boston: Brill, 2014. http://dx.doi.org/10.1163/9789004279179004

Giltaij, Jeroen. Ruffo en Rembrandt: Over een Siciliaanse verzamelaar in de zeventiende eeuw die drie schilderijen bij Rembrandt bestelde. N.p., 1997.

Giltaij, Jeroen. "Nieuws omtrent Ruffo en Rembrandt." Kroniek van het Rembrandthuis 1-2 (2005): 46-49.

Haan, A. A. M. de. "Geschiedenis van het wijsgerig onderwijs te Deventer." In Deventer denkers: De geschiedenis van het wijsgerig onderwijs te Deventer, edited by H. W. Blom, H. A. Krop, and M.R. Wielema, 29-122. Hilversum: Verloren, 1993.

Held, Julius. Rembrandt's Aristotle and Other Studies. 1969. 2nd ed. Rembrandt Studies. Princeton: 
Princeton University Press, 1991.

Hoet, Gerard. Catalogus of naamlyst van schilderyen, met derzelver pryzen zedert een langen reeks van jaaren zoo in Holland als op andere plaatzen in het openbaar verkogt, vol. 2. The Hague: Pieter Gerard van Baalen, 1752.

Hoogstraten, Samuel van. Inleyding tot de hooge schoole der Schilderkonst: anders de zichtbaere werelt. Rotterdam: François van Hoogstraten, 1678.

Jonker, Menno. "Boselli’s Philosophers Identified as Socrates and Plato." Rijksmuseum Bulletin 59, no. 2 (2011): 174-82.

Lammertse, Friso, and Jaap van der Veen. Uylenburgh \& Zoon: Kunst en commercie van Rembrandt tot De Lairesse, 1625-1675. Zwolle: Waanders, 2006.

Liedtke, Walter. “The Meaning of Rembrandt's Aristotle with a Bust of Homer." In Collected Opinions: Essays on Netherlandish Art in Honour of Alfred Bader, edited by Volker Manuth and Axel Rüger, 72-87. London: Paul Holberton, 2004.

Liedtke, Walter A. Dutch Paintings in the Metropolitan Museum of Art. 2 vols. New York: Metropolitan Museum of Art/New Haven: Yale University Press, 2007.

[Metropolitan Museum of Art] 82nd \& Fifth, The Choice / Walter Liedtke: http://82nd-and-fifth. metmuseum.org/the-choice.

Moormann, Eric M. “The man who made the song was blind': Representations of Homer in Modern Times I." Pharos: Journal of the Netherlands Institute in Athens 12 (2004): 129-50.

Moormann, Eric M. “There is a triple sight in blindness keen': Representations of Homer in Modern Times II." In Land of Dreams: Greek and Latin Studies in Honour of A. H. M. Kessels, edited by A. P. M. H. Lardinois, M. G. M. van der Poel, and V. J. C. Hunink, 229-56. Leiden and Boston: Brill, 2006.

Orsini, Fulvio. Imagines et elogia virorum illustrium et eruditor ex antiquis lapidibus et nomismatib expressa ... Rome: Antonio Lafreri, 1570.

Rademaker, Cor. "Wetenschappelijke handboeken die groot nieuws waren." In Orbis doctus, 1500-1850: Perspectieven op de geleerde wereld van Europa; plaatsen en personen; opstellen aangeboden aan professor dr. J. A. H. Bots, edited by G. C. A. M. van Gemert, F. J. M. Korsten, P. J. A. N. Rietbergen, and J. J. V. M. de Vet, 237-53. Amsterdam and Utrecht: APA-Holland Universiteits Pers, 2005.

Remmert, Volker R. “Docet parva pictura, quod multae scripturae non dicunt': Frontispieces, Their Functions, and Their Audiences in Seventeenth-Century Mathematical Sciences.” In Transmitting Knowledge: Words, Images, and Instruments in Early Modern Europe, edited by Sachiko 
Kusukawa and Ian Maclean, 239-70. Oxford: Oxford University Press, 2006.

Ricci, C. Rembrandt in Italia. Milan: Alfieri and Lacroix, 1918.

Rutgers, Jaco. “Rembrandt in Italië: Receptie en verzamelgeschiedenis.” PhD diss., University of Utrecht, 2008.

Salman, Jeroen. Populair drukwerk in de Gouden Eeuw: De almanak als lectuur en handelswaar. Zutphen: Walburg Pers, 1999.

Sandrart, Joachim von. Academia todesca delia architectura, scultura e pittura: Oder Teutsche Academie der Edlen Bau-Bild- und Mahlerey-Künste . . . Nuremberg: Joachim von Sandrart, $1675-80$.

Saxl, Fritz. "Rembrandt and Classical Antiquity." 1957. In Seventeenth Century Art in Flanders and Holland, edited by J. S. Ackerman et al., 189-211. Garland Library of the History of Art 9. New York and London: Garland Publishing, 1976.

Schenkeveld-van der Dussen, M.A. Nederlandse literatuur in de tijd van Rembrandt. Utrecht: Bijleveld, 1994.

Schwartz, Gary. Rembrandt: Zijn leven, zijn schilderijen; Een nieuwe biografie met alle beschikbare schilderijen in kleur afgebeeld. Maarssen: Gary Schwartz, 1984.

Sheers Seidenstein, Joanna. “Grace, Genius, and the Longinian Sublime in Rembrandt's Aristotle with a Bust of Homer.” JHNA 8, no. 2 (2016). http://dx.doi.org/10.5092/jhna.2016.8.2.5

Sluijter, Eric Jan. "Rembrandt's Portrayal of the Passions and Vondel's 'staetveranderinge." The Passions in the Arts of the Early Modern Netherlands / De hartstochten in de kunst in de vroegmoderne Nederlanden, edited by Stephanie S. Dickey and Herman Roodenburg. Special issue. Nederlands Kunsthistorisch Jaarboek 60 (2010): 285-305.

Sonnenburg, Hubert von, Walter Liedtke, Carolyn Logan, Nadine M. Orenstein, and Stephanie S. Dickey, eds. Rembrandt/Not Rembrandt in the Metropolitan Museum of Art: Aspects of Connoisseurship. 2 vols. New York: Metropolitan Museum of Art, 1995.

Spinosa, Nicola. Ribera. Naples: Electa, 2006.

Thevet, André. Les vrais pourtraits et vies des hommes illustres Grecz, Latins, et payens recueilliz de leur tableaux, livres, medalles antiques \& modernes . . Paris: I. Kervert et G. Chaudiere, 1584.

Tümpel, Christian. Rembrandt. Antwerp: Mercatorfonds, 1986.

Valentiner, Wilhelm R. "Rembrandt at the Latin School." In Seventeenth Century Art in Flanders 
and Holland, edited by J. S. Ackerman et al., 123-24. Garland Library of the History of Art 9. New York and London: Garland Publishing, 1976.

Verhaak, Els. "Filosofen naar Spaanse voorbeelden door Bernard Vaillant: Een oeuvre wordt uitgebreid." Bulletin van het Rijksmuseum 34, no. 34 (1986): 247-55.

Vondel, Joost van den. Den Gulden Winckel der Konstlievende Nederlanders. Gestoffeert met veel treffelijcke historische, Philosophische, Poeetische morale ende schriftuerlijcke leeringen. Geciert met schoone kunstplaten oft Beeldenissen. Vermakelyck en stichtelijck voor alle staten van Menschen. Amsterdam: Dirck Pietersz, 1613.

Weststeijn, Thijs. "De zichtbare wereld: Samuel van Hoogstratens kunsttheorie en de legitimering van de schilderkunst in de zeventiende eeuw." PhD diss., University of Amsterdam, 2005.

Wetering, Ernst van de, ed. A Corpus of Rembrandt Paintings, Part 4: The Self-Portraits. Dordrecht: Springer, 2005.

Winkel, Marieke de. Fashion and Fancy: Dress and Meaning in Rembrandt's Paintings. Amsterdam: Amsterdam University Press, 2006.

Recommended Citation:

Menno Jonker, "Rembrandt's Philosopher: Aristotle in the Eye of the Beholder," JHNA 9:1 (Winter 2017) D0I: 10.5092/

jhna.2017.9.1.12 